\title{
Effect of Technological Advancement on Performance of Rapeseed Mustard Varieties Assessed under Zero-till and Utera Conditions in Rice Fallow Areas of Madhya Pradesh
}

\author{
Shiv Ratan* and Yogranjan Singh
}

AICRP on Sesame, College of Agriculture, Tikamgarh, India

*Corresponding author

\section{A B S T R A C T}

\begin{tabular}{|l}
\hline Ke y w o r d s \\
$\begin{array}{l}\text { Rapeseed Mustard, } \\
\text { Zero-till and } \\
\text { Utera Conditions }\end{array}$ \\
\hline Article Info \\
\hline $\begin{array}{l}\text { Accepted: } \\
\text { 10 January } 2021 \\
\text { Available Online: } \\
\text { 10 February } 2021\end{array}$
\end{tabular}

\section{Introduction}

India has 11.65 million ha. Rice-fallow area which is a challenge to grow crops in residual moisture during rabi as well as an opportunity to increase oilseeds and pulses production for self -sufficiency in such areas. In Madhya Pradesh, 4.38 million hectare area remains as rabi rice fallow (Anon., 2013 and Masood Ali et al., 2016) which is $78.3 \%$ of kharif rice area due to lack of irrigation facilities and absence of suitable varietal, mechanical and scientific interventions to grow crops on residual moisture after harvest of kharif rice. Rapeseed- mustard are best potential crops having fast growing early maturing and tolerant to terminal moisture stress, salt, insect pests and diseases. Rapeseed-mustard group of crops are grown on wide range of ecology right from semi-arid tracts to temperate regions indicating its sustaining capabilities. These crops contributed 7.92 million tonnes seed yield and $22.4 \%$ oil to total edible oil produced in India in 2017-18 (Anonymous, Commodity Profile of Edible Oils for Sept. 2019).

Recently, India has achieved self sufficiency in pulses production by producing 24.51 million tonnes against the demand of 23.44 million tonnes in 2017-18 (GOI) while 15.01 million tonnes edible oils of worth Rs. 66.7 
thousand crores were imported in the year 2018-19 indicating a huge gap in demand and production. (Anonymous, Commodity Profile of Edible Oils for Sept. 2019). Hence, it is an opportunity for horizontal expansion of area which remains fallow after kharif rice to reduce import currency load. Residual soil moisture in the surface layer at the time of planting rabi crops is the major constraints in rice fallows lacking irrigation source. Hence, Zero- till seed-cum -fertilizer drill used for planting selected rape-seed - mustard cultivars after harvest of kharif rice crop to save moisture and energy waste during land preparations.

Therefore, this study was intended to promote rainfed rabi rapeseed mustard crops for rice fallow areas of Madya Pradesh by providing varietal, mechanical and technical support to farmers for the genesis of one more source of income.

\section{Materials and Methods}

For this current study, farmers were selected on participatory basis at three locations viz; Jatara, Baldevgarh and Tikamgarh blocks of Tikamgarh district in Madya Pradesh and provided short duration well adapted varieties of rape seed mustard group including toria, yellow sarson and Indian mustard. Further, zero-till-cum fertilizer seed drill was used for sowing to take maximum advantage of residual soil moisture and minimize moisture losses during tillage operations after harvest of rice crop. This experiment comprised of eight varieties grown in Randomized Block Design with three replication at each three locations for Utera as well as Zero-till conditions. Observations were recorded on competitive five plants from each replication at all three locations for ancillary traits as well as seed yield under both conditions and data analyzed as per standards methods of Panse and Sukhatme, 1978.
Technological advancement comprised as under

Varieties used: NRCHB 101, PM 25, Pitambra, DRMRIJ-31, YSH 401, RH 406, Tapeshwari and Bhawani

Mechanization: Zero-till-cum fertilizer seed drill

Scientific support: Training and Field days Method of sowing: Zero-till and Utera

The prevailing rates of wages, inputs, diesel and produce were used for calculation of costs and income parameters.

\section{Results and Discussion}

Figure-1 depicted that mean seed yield over three location recorded higher in all the cultivars under zero-till as compared to utera condition (Singh et al., 2014 and Mohammad et al., 2019). A significantly higher seed yields were harnessed from variety NRCHB 101 followed by Pitambra proved their superiority over rest of entries (Jat et al., 2018). Although, yield difference between both varieties were found statistically nonsignificant. 50\% flowering ranged from 49 to 63 DAS under Utera while same was ranged from 53 to 65 DAS. Variety Bhawani followed by Tapeshwari recorded earliest under utera as well as zero-till. Likewise, variety Bhawani recorded as dwarf and DRMRIJ 31 recorded as tallest under both Utera and Zero-till conditions. Primary branches per plant found highest in Tapeshwari and Bhawani in utera and zero-till conditions, respectively. The higher variability was observed for plant population under Utera condition. The number of silique was recorded higher in zero-till as compared to Utera condition. The highest siliquae per plant were observed in RH 406 (130) and PM 25 (136) under utera and zero-till condition, respectively. 
Table.1 Pooled comparative mean data of various agro-morphological traits of rapeseed-mustard under zero-till and utera

\begin{tabular}{|c|c|c|c|c|c|c|c|c|c|c|c|c|c|c|c|c|}
\hline \multirow{2}{*}{$\begin{array}{l}\text { Traits } \\
\text { Varieties }\end{array}$} & \multicolumn{2}{|c|}{ 50\% Flowering (DAS) } & \multicolumn{2}{|c|}{ Maturity days (DAS) } & \multicolumn{2}{|c|}{ Plant Height (cm) } & \multicolumn{2}{|c|}{ Primary branches / plant } & \multicolumn{2}{|c|}{ No. of siliquae / plant } & \multicolumn{2}{|c|}{ No. of seeds / plant } & \multicolumn{2}{|c|}{ 1000- seed weight $(\mathrm{g})$} & \multicolumn{2}{|c|}{ Plant Population ('000) } \\
\hline & UT & ZT & UT & $\mathbf{Z T}$ & UT & $\mathbf{Z T}$ & UT & $\mathbf{Z T}$ & UT & $\mathrm{ZT}$ & UT & $\mathrm{ZT}$ & UT & $\mathrm{ZT}$ & UT & ZT \\
\hline NRCHB 101 & 61 & 63 & 118 & 119 & 119 & 119 & 3.9 & 4.3 & 128 & 132 & 12.3 & 12.7 & 5.0 & 5.1 & 230 & 300 \\
\hline PM 25 & 58 & 61 & 117 & 118 & 128 & 133 & 3.8 & 4.7 & 129 & 136 & 14.0 & 14.1 & 4.8 & 4.9 & 260 & 290 \\
\hline Pitambra & 63 & 65 & 116 & 120 & 88 & 88 & 4.1 & 4.2 & 116 & 121 & 14.5 & 14.7 & 3.7 & 3.8 & 270 & 270 \\
\hline DRMRIJ-31 & 57 & 63 & 118 & 117 & 181 & 184 & 4.1 & 4.5 & 127 & 130 & 13.3 & 13.4 & 5.5 & 5.5 & 290 & 310 \\
\hline YSH 401 & 60 & 65 & 117 & 119 & 76 & 85 & 4.3 & 3.9 & 112 & 114 & 14.2 & 14.5 & 4.3 & 4.3 & 350 & 310 \\
\hline RH 406 & 57 & 64 & 117 & 118 & 176 & 179 & 4.4 & 4.1 & 130 & 135 & 13.6 & 14.0 & 5.5 & 5.8 & 270 & 290 \\
\hline Tapeshwari & 49 & 53 & 110 & 112 & 101 & 101 & 5.3 & 4.6 & 119 & 117 & 11.7 & 12.2 & 3.5 & 3.5 & 270 & 300 \\
\hline Bhawani & 49 & 54 & 109 & 111 & 79 & 78 & 5.1 & 4.9 & 110 & 121 & 10.5 & 11.2 & 3.6 & 3.5 & 270 & 280 \\
\hline Mean & 57 & 61 & 115 & 117 & 118 & 121 & 4.4 & 4.4 & 121 & 126 & 13.0 & 13.3 & 4.5 & 4.5 & 280 & 290 \\
\hline SEM= & 1.51 & 0.63 & 1.09 & 1.06 & 5.35 & 3.27 & 0.36 & 0.42 & 5.39 & 5.22 & 0.44 & 0.40 & 0.14 & 0.21 & 2.40 & 1.21 \\
\hline $\mathrm{CD}(p=0.05)$ & 4.31 & 1.80 & 3.10 & 3.01 & 15.29 & 9.33 & 1.01 & 1.20 & 15.39 & 14.91 & 1.24 & 1.13 & 0.40 & 0.59 & 6.85 & 3.46 \\
\hline $\mathrm{CV}=$ & 4.61 & 1.79 & 1.63 & 1.57 & 7.83 & 4.69 & 14.01 & 16.52 & 7.70 & 7.20 & 5.79 & 5.15 & 5.42 & 7.89 & 15.05 & 7.19 \\
\hline
\end{tabular}

Table.2 Comparative status of financial parameters (per hectare)

\begin{tabular}{|l|l|c|c|}
\hline S.No & Particulars & Utera & Zero-till \\
\hline $\mathbf{1}$ & Common cost (Rs.) & 13893 & 15893 \\
\hline $\mathbf{2}$ & Treatment cost (Rs.) & 1621 & 1621 \\
\hline $\mathbf{3}$ & Total cost (Rs.) & 15514 & 17514 \\
\hline $\mathbf{4}$ & Total Income (Rs.) & 30263 & 36965 \\
\hline $\mathbf{5}$ & B:C ratio & 1.95 & 2.11 \\
\hline
\end{tabular}


Fig.1 Relative performance of rapeseed-mustard varieties under utera and zero-till conditions

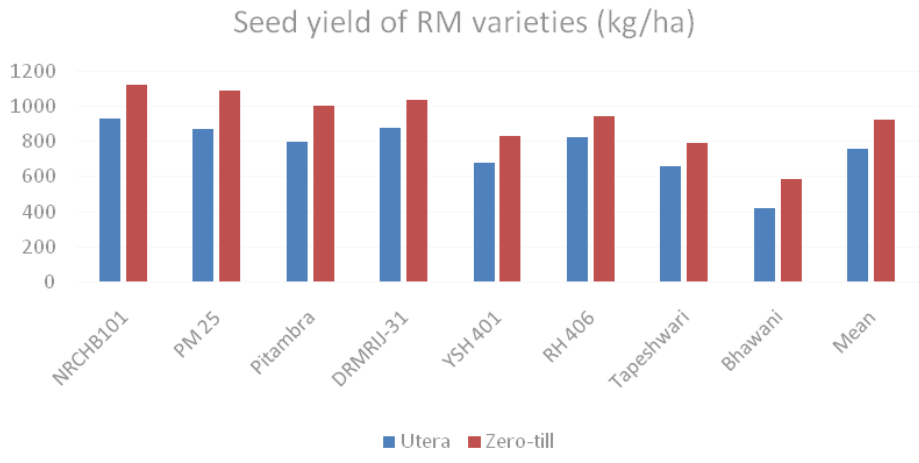

Cultivar Pitambra shown its statistical superiority for number of seeds per siliqua over rests under both Utera and Zero-till condition (Table-1). The traits viz., No. of siliquae / plant, primary branches / plant and test weight remain same under both methods of planting. A significantly higher 1000 seed weight was recorded in DRMRIJ 31, RH 406 and NRCHB 101under Utera as well as Zerotill condition.

Table-2 depicted that mean common cost / hectare over three locations was recorded higher under zero-till due to difference in tractor and labour use while treatment cost remained same under both conditions. The mean per hectare income over three locations was recorded Rs. 36965 under Zero-till which was Rs. $6702 /$ ha. more than the income under utera condition. Similar trend of results were recorded by Jat et al., (2018) and Verma et al., (2017). In addition to this, cost benefit $(\mathrm{B}: \mathrm{C})$ ratio was recorded 1.95 under Utera while 2.11 under zero-till condition (Rawat et al., 2007) which is quite convincing that by adopting improved technologies, farmers can earn more income per unit area.

In conclusion the mean seed yield over three locations recorded higher in all the cultivars under zero-till as compared to utera condition. A significantly higher seed yields were harnessed from variety NRCHB 101 followed by PM 25 proved their statistical superiority over rest of entries. The mean per hectare income over three locations was recorded Rs. 36965 under Zero-till which is about $22 \%$ higher in comparison to Utera.

\section{Acknowledgement}

This study was conducted under GOI funded external collaborative project - Technological Advancement and assessment for rapeseedmustard production in rice fallow areas of Eastern India.

\section{References}

Ali, M., S.S. Singh, Sarkar, A and Agrawal, S.K. 2016. Rice fallows-An opportunity for horizontal expansion of Pulses. Science. Int. Conference on pulses in Marrakesh, morocco, 18-20 April2016.

Anonymous., 2013. NAAS Policy paper 64.

Anonymous., 2017-18. Data of rapeseed mustard; www.srmr.org.in/nbc

Anonymous., 2019. Commodity Profile of Edible Oils.

Panse, V.G. and Sukhatme, P.V. 1978. Statistical methods for Agriculture workers. ICAR, New Delhi, 235-246.

Anonymous., 2017-18. Pulses Revolution Report of GOI

Jat, R.S, V.V. Singh, P. Sharma, J. Salam and Legha, S.R. 2018. Gene x environment 
$\mathrm{x}$ management effects on seed yield seed yield of rapeseed-mustard production in rice fallow system. XXI Biennial National Symposium of Agronomy, MPUAT, Udaipur, Raj., 2426 October 2018.

Mohammad, Quasim, A.K. Shrivastava, S.K. Rautaray and Gautam, A.K. 2019. Comparative evaluation of zero-till slit seed drill and combined tillage and seeding equipment in rice. Int. J. Curr. Microbial. App. Sci. 8(6):132-149.

Singh, P., S. Singh and Singh, B.R. 2014. Performance of Zero-till drill for wheat cultivation at farmers field. Int. J. Sci and Res, 3(7): 2078-84.

Rawat, S.N., M.R., Verma, S.K., Goyal and Dave, A. K. 2007. Cost economic evaluation of zero-till fertilizer seed drill vs conventional method of sowing. Prog. Agric. 7(1/2): 161-162.

Singh, P., S., Singh and B.R., Singh, and Mishra, D. K. 2014. Performance evaluation of zero-till fertilizer seed drill in comparison to conventional and reduced tillage method of wheat crop on the same day. Int. J. Sci and Res, 4(8): 1-4.

Verma, P.D., Parmanad and Tamarka, S.K. 2017. A comparison of zero-till technology and traditional techniques for sowing of wheat -Evidence from farmers field by FLDs. Int. J. of Agric. Innovations and Res. 5(6): 1016-1019.

\section{How to cite this article:}

Shiv Ratan and Yogranjan Singh. 2021. Effect of Technological Advancement on Performance of Rapeseed Mustard Varieties Assessed under Zero-till and Utera Conditions in Rice Fallow Areas of Madhya Pradesh. Int.J.Curr.Microbiol.App.Sci. 10(02): 1344-1348. doi: https://doi.org/10.20546/ijcmas.2021.1002.159 